\title{
Kemampuan Pemecahan Masalah Siswa pada Materi Suhu dan Kalor melalui Experiential Learning Berbasis Fenomena
}

\author{
Prima Warta Santhalia ${ }^{1}$, Lia Yuliati ${ }^{1}$, Hari Wisodo ${ }^{1}$ \\ ${ }^{1}$ Pendidikan Fisika-Universitas Negeri Malang
}

\begin{tabular}{l}
\hline \hline INFO ARTIKEL \\
\hline Riwayat Artikel: \\
Diterima: 11-01-2019 \\
Disetujui: 13-02-2019 \\
\hline
\end{tabular}

Kata kunci:

experiential learning; problem solving skill; heat and temperature; kemampuan pemecahan masalah; panas dan suhu

\begin{abstract}
ABSTRAK
Abstract: This research was aimed to describe problem solving skill in Experiential Learning based on the phenomenon, particularly about heat and temperatur. This study was conducted using mix method approach with embedded experimental model research design. The data were collected through pretest and posttest using test and interview. The result of $\mathrm{N}$-Gain Score calculation showed that there are increase in student's skill on solving problem about temperature and calorie is in moderate category, and the result of d-cohen effect size is in moderate category. At the same time the result of qualitative calculation on student solving skill showed there are 9,4\% students in low category, $53,1 \%$ student in medium category, and $37,5 \%$ student are in high category after experiencing phenomenon based Experimental Learning. Student's skill in problem solving has to be practiced more intensively using real-life problem in daily life.
\end{abstract}

\begin{abstract}
Abstrak: Penelitian ini bertujuan untuk mendeskripsikan kemampuan pemecahan masalah siswa dalam pembelajaran Experiential Learning berbasis fenomena terutama pada suhu dan kalor. Penelitian ini menggunakan pendekatan mix method dengan desain penelitian embedded experimental model. Data dikumpulkan melalui pretest dan posttest menggunakan tes dan wawancara. Hasil perhitungan N-Gain score menunjukkan adanya peningkatan kemampuan siswa dalam memecahkan suhu dan kalor dalam kategori sedang dan hasil perhitungan $d$-cohen effect size dalam kategori sedang. Sementara itu, hasil perhitungan kualitatif kemampuan pemecahan masalah siswa melalui crosstabulation menunjukkan sebanyak $9,4 \%$ siswa berada pada kategori rendah, 53,1\% siswa pada kategori sedang, dan 37,5\% siswa pada kategori tinggi setelah mengalami Experiential Learning berbasis fenomena. Kemampuan pemecahan masalah siswa perlu dilatih lebih intensif menggunakan masalah nyata dalam kehidupan sehari-hari.
\end{abstract}

\author{
Alamat Korespondensi: \\ Prima Warta Santhalia \\ Pendidikan Fisika \\ Universitas Negeri Malang \\ Jalan Semarang 5 Malang \\ E-mail: primawartas@gmail.com
}

Konsep fisika yang bersifat abstrak menyebabkan banyak terjadi miskonsepsi di kalangan siswa pada jenjang Sekolah Menengah Atas terutama materi mekanika, optik, listrik, dan termodinamika (Antwi \& Aryeetey, 2015; Celik, 2016; Gonen \& Kocakaya, 2009; Kartal, Öztürk, \& Yalvaç, 2011; Madu \& Orji, 2015). Materi suhu dan kalor merupakan salah satu konsep fisika yang bersifat abstrak sehingga menyebabkan banyak terjadinya miskonsepsi pada siswa (Kartal, Öztürk, \& Yalvaç, 2011; Madu \& Orji, 2015). Hal ini disebabkan karena konsep suhu dan kalor tidak secara langsung dapat diamati secara kuantitatif (Antwi \& Aryeetey, 2015; Leura, Otto, \& Zitzewitz, 2011). Siswa juga salah menghubungkan konsep dengan pengalaman sehari-hari mereka sehingga memiliki pemahaman awal yang cukup keliru dan tidak dapat dibuktikan secara ilmiah (Antwi \& Aryeetey, 2015; Celik, 2016; Gonen \& Kocakaya, 2009; Kartal, Öztürk, \& Yalvaç, 2011; Madu \& Orji, 2015).

Miskonsepsi yang banyak terjadi pada konsep suhu dan kalor tentu tidak dapat diabaikan begitu saja, karena konsep ini merupakan salah satu konsep dasar yang digunakan untuk memahami konsep ilmiah lainnya dari jenjang sekolah dasar hingga perguruan tinggi (Gonen \& Kocakaya, 2009). Oleh karena itu, penguasaan konsep pada materi ini perlu diperhatikan agar konsepsi alternatif tidak kembali membayangi konsepsi siswa (Aryani, Handayanto, \& Wisodo, 2016). Penguasaan konsep merupakan bagian terpenting dalam proses pemecahan masalah (Sabella \& Redish, 2007). Beberapa hasil penelitian juga menyatakan penguasaan konsep yang baik merupakan dasar dari pemecahan masalah fisika siswa (Docktor, Strand, Mestre, \& Ross, 2015). 
Kemampuan pemecahan masalah merupakan kemampuan individu yang melibatkan pemrosesan kognitif yang merupakan bagian dari pengalaman sehari-hari (Adams \& Wieman, 2015; Gok, 2010; Mayer, 2013). Dalam konteks penilaian berskala besar seperti PISA, pemecahan masalah diartikan sebagai kemampuan lintas disiplin dan dunia nyata yang menerapkan kemampuan kognitif seperti penalaran dan pemikiran logis (OECD, 2012). Kemampuan pemecahan masalah merupakan salah satu kemampuan yang sangat penting pada pembelajaran fisika yang harus diaplikasikan dalam mengukur tingkat pemahaman yang dimiliki siswa (Adams \& Wieman, 2015; Docktor, Strand, Mestre, \& Ross, 2015). Banyak penelitian yang telah dilakukan terkait pemecahan masalah yang menunjukan hasil yang kurang baik. Penelitian yang dilakukan oleh Alias \& Ibrahim (2015) menunjukan bahwa kemampuan pemecahan masih berada dalam kategori rendah. Hasil yang sama juga diperoleh oleh penelitian yang dilakukan oleh (Argaw, 2017; Mansyur, 2015) yang menunjukkan bahwa kemampuan pemecahan masalah fisika siswa masih berada pada kategori sangat rendah.

Tingkat kemampuan pemecahan masalah siswa yang masih dalam kategori rendah salah satunya dipengaruhi oleh kemampuan kognitif dan kemampuan representasi penyelesaian masalah yang dilakukan oleh siswa (Staggers and Norcio, 1993). Jonassen (2011) menguraikan indikator dari kemampuan pemecahan masalah yaitu problem scema, analogical comparison, causal relationship, questioning, modeling, argumentation, and metacognitve regulation. Pada indikator pertama Problem schema mencakup informasi yang berkaitan dengan kehidupan sehari-hari. Indikator kedua analogical comparison mencakup penalaran yang menghubungkan dua kejadian untuk memecahkan masalah. Indikator ketiga causal relationships mencakup hubungan sebab akibat dari suatu kejadian. Indikator keempat argumentation mencakup pemberian argumen atau solusi yang tepat dari masalah yang diberikan.

Kerangka pemecahan masalah PISA 2015 merekomendasikan pemecahan masalah siswa, sebaiknya tidak hanya berfokus pada solusi akhir saja, akan tetapi pada proses dan pemahaman konsep siswa dalam menentukan strategi yang cocok untuk menemukan solusi (OECD, 2012). Pembelajaran pengembangan kemampuan memecahkan masalah siswa dapat dilakukan dengan penerapan strategi pembelajaran yang memegang beberapa prinsip pada abad 21 yakni, pembelajaran yang relevan dan dibutuhkan dalam kehidupan nyata/kontekstual (Glaze, 2018; Saavedra \& Opfer, 2012). Strategi pembelajaran yang sesuai dengan prinsip tersebut salah satunya adalah Experiential Learning berbasis fenomena (Gorghiu \& Santi, 2016). Experiential Learning berbasis fenomena adalah proses membangun pengetahuan berdasarkan pengalaman dan konteks kehidupan nyata yang melibatkan siswa dalam mengerjakan tugas, memecahkan masalah, atau melakukan proyek melalui umpan balik, penguatan konsep dan penerapan pengetahuan dalam situasi yang baru (Kolb, 2008; Kolb, 2015).

Penelitian ini bertujuan untuk mengeksplorasi kemampuan pemecahan masalah siswa pada suhu dan kalor dengan Experiential Learning berbasis fenomena. Melalui eksplorasi kemampuan pemecahan masalah siswa, guru dapat mengetahui kemampuan yang dimiliki oleh siswa dalam memahami dan menerapkan konsep suhu dan kalor untuk memecahkan permasalahan. Hasil kajian dari eksplorasi kemampuan pemecahan masalah siswa pada materi suhu dan kalor dengan Experiential Learning berbasis fenomena dapat menjadi informasi yang penting untuk melakukan kajian lebih lanjut terkait kemampuan pemecahan masalah siswa.

\section{METODE}

Penelitian ini menggunakan pendekatan mixed methods dengan desain penelitian embedded experimental model. Subjek dari penelitian ini terdiri dari 32 siswa kelas XI SMA Negeri 7 Malang. Pada pembelajaran materi suhu dan kalor dilaksanakan sebanyak enam kali pertemuan. Pada pertemuan pertama diberikan pretest sebanyak 10 soal uraian terkait materi suhu dan kalor untuk mengukur kemampuan pemecahan masalah awal siswa sebelum diterapkan pembelajaran Experiential learning berbasis fenomena. Pada pertemuan kedua hingga keempat, siswa diberi perlakuan pada materi suhu dan kalor berupa pembelajaran Experiential learning berbasis fenomena. Pada pertemuan yang keenam siswa diberikan posttest dengan memberikan soal sebanyak 10 soal uraian dengan jenis soal yang diberikan sama dengan soal pretest. Hasil penelitian kemampuan pemecahan masalah siswa yang diperoleh kemudian dianalisis secara kuantitatif dan kualitatif. Data kuantitatif berupa skor tes kemampuan pemecahan masalah siswa pada saat pretest dan posttest yang dianalisis dengan Uji effect size, Uju N-gain, dan Uji t berpasangan. Sedangkan pada data kualitatif diperoleh dari hasil wawancara siswa saat menyelesaikan tes kemampuan pemcahan masalah pada pretest dan posttest yang dianalisis dengan menggunakan koding dan reduksi data.

\section{HASIL}

\section{Deskripsi Statistik Peningkatan Kemampuan Pemecahan}

Analisis kemampuan pemecahan masalah siswa diawali dengan analisis deskriptif dengan tujuan untuk mendeskripsikan kemampuan pemecahan masalah siswa sebelum dan sesudah pembelajaran Experiential Learning berbasis fenomena. Hasil peningkatan kemampuan pemecahan masalah siswa dinyatakan dengan nilai rata-rata N-Gain. Hasil analisis statistik kemampuan pemecahan masalah ditunjukan pada Tabel 1.

Sebelum melakukan uji beda menggunakan paired $t$-Test, dilakukan uji normalitas sebagai uji prasyarat analisis statistik parametrik. Berdasarkan hasil uji prasayarat normalitas, data pretest dan posttest kemampuan pemecahan masalah siswa terdistribusi normal. Hal ini dibuktikan dengan menggunakan Shapiro-walk diperoleh nilai signifikasi pretest dan posttest yaitu sebesar 0,057 dan 0,546 yang lebih besar dari taraf siginifikan 0,05. 
Tabel 1. Analisis Statistik Kemampuan Pemecahan Masalah

\begin{tabular}{ccc}
\hline Statistik & Pretest & Posttest \\
\hline Jumlah Sampel & 32 & 32 \\
Nilai Maksimum & 30,00 & 85,00 \\
Nilai Minimum & 7,50 & 25,00 \\
Mean & 22,66 & 56,88 \\
Standar Deviasi & 1,004 & 2,57 \\
Shapiro-walk & $0,0057($ sig) & $0,546($ sig) \\
\hline
\end{tabular}

Setelah diketahui data terdistribusi normal maka peningkatan kemampuan pemecahan masalah dilanjutkan dengan uji $N$-Gain, Effect Size, dan Uji-t berpasangan. Berdasarkan hasil perhitungan yang diperoleh, kemampuan pemecahan masalah siswa yang mengalami pembelajaran Experiential Learning berbasis fenomena mengalami peningkatan dalam kategori sedang yaitu sebesar 0,44. Kekuatan pembelajaran Experiential Learning berbasis fenomena terhadap kemampuan pemecahan masalah siswa termasuk dalam kategori kuat dengan nilai effect size 1,21. Uji beda berpasangan dilakukan dengan menggunakan SPSS, diperoleh hasil yang ditunjukan pada Tabel 2.

Tabel 2. Uji Beda Berpasangan

\begin{tabular}{ccc}
\hline Statistik & Nilai & Kategori \\
\hline Nilai t & 13,440 & Perbedaan Signifikan \\
Asymp (2-tailed) & 0,000 & Posttest $>$ Pretest \\
Paired Sample Test & & \\
\hline
\end{tabular}

Tabel 2 menunjukkan nilai uji beda diperoleh sebesar 13,440 dengan nilai asymp (2-tailed) sebesar 0,000 yang menunjukan nilai pretest dan posttest bebeda secara signifikan. Selain itu ditunjukan paired Sample Test dimana nilai kemampuan pemecahan masalah meningkat dari pretest ke posttest.

\section{Deskripsi Peningkatan Kemampuan Pemecahan Masalah Siswa}

Peningkatan Kemampuan pemecahan masalah siswa pada materi suhu dan kalor yang mengalami pembelajaran Experiential Learning berbasis fenomena dapat dilihat dari peningkatan nilai pretest dan posttest. Hasil jawaban pretest dan posttest siswa disajikan pada Gambar 1.

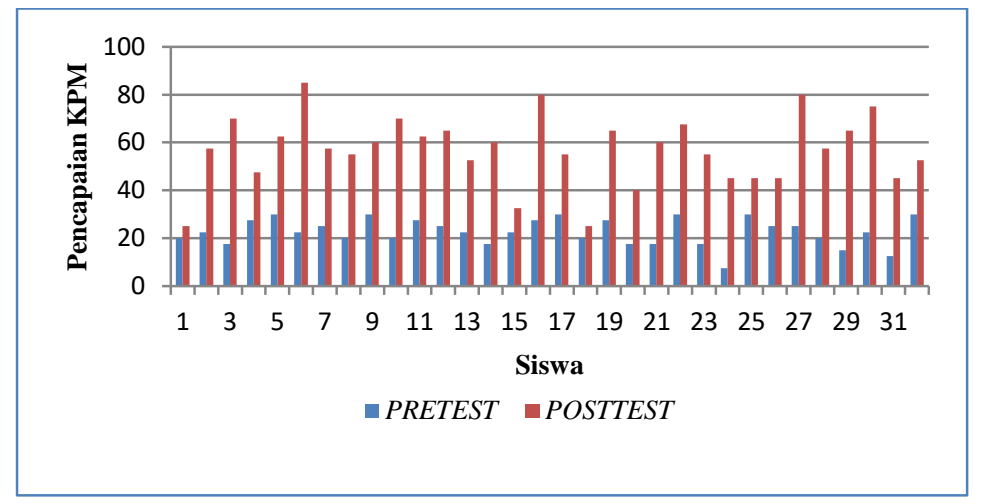

\section{Gambar 1. Kemampuan Pemecahan Masalah Pretest dan Posttest}

Berdasarkan Gambar 1 diperoleh peningkatan kemampuan pemecahan masalah siswa pada pretest dan posttest mengalami peningkatan pada tiap-tiap individu. Beberapa siswa mengalami peningkatan KPM secara signifikan, hal ini terlihat pada siswa nomor urut 3 (dari 18 menjadi 70), nomor urut 6 (dari 23 menjadi 85), nomor urut 10 (dari 20 menjadi 70 ), nomor urut 16 (dari 28 menjadi 80) dan nomor urut 24 (dari 8 menjadi 45). Selain itu ada beberapa siswa yang sedikit mengalami kenaikan pada nilai pretest dan posttest, yaitu pada nomor 1 (dari 20 menjadi 25) dan nomor 25 (dari 30 menjadi 45). Berdasarkan nilai pretest dan posttest kemampuan pemecahan masalah yang dikelompokkan selanjutnya dianalisis menggunakan Crosstabulation, sehingga diperoleh hasil peningkatan kemampuan pemecahan masalah pada tiap-tiap individu yang disajikan pada Tabel 3 . 
Tabel 3. Crosstabulation Nilai Pretest dan Posttest Kemampuan Pemecahan Masalah Siswa

\begin{tabular}{ccccccc}
\hline & & \multicolumn{5}{c}{ KPM Posttest } \\
\cline { 3 - 6 } & & Sangat Tinggi & Tinggi & Sedang & Rendah & Tidak Dapat Digolongkan \\
\cline { 2 - 6 } KPM & Sangat Tinggi & 0 & 0 & 0 & 0 & 0 \\
Pretest & Tinggi & 0 & 0 & 0 & 0 & 0 \\
& Sedang & 0 & 0 & 0 & 0 & 0 \\
& Rendah & 0 & 12 & 16 & 3 & 0 \\
& Tidak Dapat Digolongkan & 0 & 0 & 1 & 0 & 0 \\
\hline
\end{tabular}

Pada Tabel 3 analisis crosstabulation, kemampuan pemecahan masalah siswa dikelompokkan menjadi 4 kategori yaitu sangat tinggi, tinggi, sedang, dan rendah. Berdasarkan Tabel 3 diperoleh nilai pretest siswa berada dalam dua kategori yaitu rendah dan tidak dapat digolongkan. Sedangkan untuk nilai posttest siswa berada dalam tiga kategori yaitu tinggi, sedang dan rendah. Siswa yang memiliki kemampuan pemecahan masalah yang tidak dapat digolongkan adalah siswa yang nilainya 0 , sedangkan untuk yang memiliki nilai 1 termasuk dalam ketegori rendah, nilai 2 sedang, nilai 3 tinggi, dan nilai 4 sangat tinggi. Sebagian besar siswa mengalami peningkatan kemampuan pemecahan masalah dari yang rendah dan tidak dapat digolongkan menjadi sedang dan tinggi, walaupun ada sebagian kecil siswa yang tidak mengalami peningkatan KPM. Hasil pretest menunjukkan bahwa siswa yang memiliki KPM pada kategori" tidak dapat digolongkan" hanya 1 siswa, dan pada saat posttest berubah menjadi kategori "sedang". Sementara itu, hasil pretest pada kategori "rendah" sebanyak 31 siswa dan pada saat posttest berubah menjadi 12 siswa berada dalam kategori "tinggi", 16 siswa dalam kategori "sedang" dan tiga siswa tetap berada pada kategori "rendah". Berdasarkan hasil tersebut dapat dikatakan bahwa semua siswa memiliki kemampuan pemecahan masalah yang dapat dikategorikan, yaitu sebanyak tiga siswa pada kategori rendah (9,4\%), 17 siswa pada kategori sedang $(53,1 \%)$, dan 12 siswa pada kategori tingggi $(37,5 \%)$.

\section{Deskripsi Kemampuan Pemecahan Masalah Berdasarkan Indikator}

Indikator Kemampuan pemecahan masalah yang digunakan dalam penelitian ini terdiri dari empat indikator, yaitu Argumentation, analogical, causal, dan problem schema. Distribusi rata-rata untuk setiap indikator kemampuan pemecahan masalah siswa setelah diajar menggunakan Experiential learning berbasis fenomena dapat dilihat pada Gambar 2.

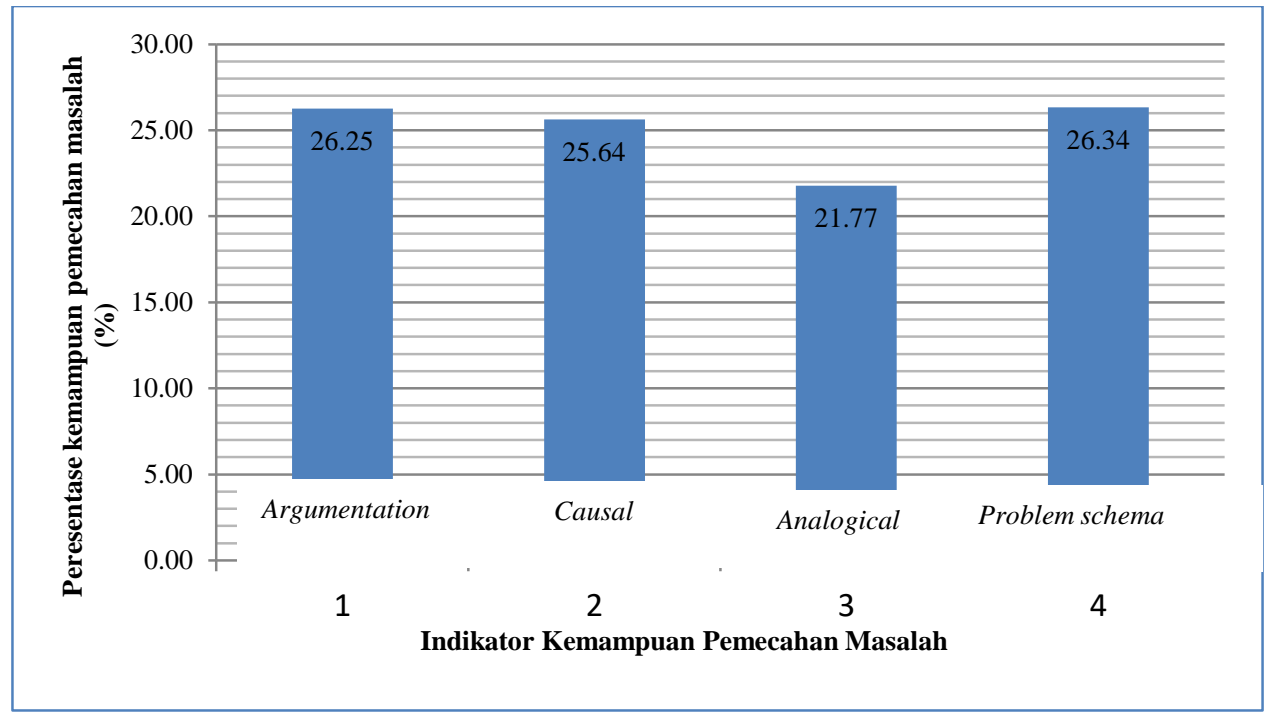

Gambar 2. Persentase Kemampuan Pemecahan Masalah pada Pembelajaran Experiential Learning Berbasis Fenomena

Berdasarkan Gambar 2 diperoleh bahwa indikator problem schema memiliki persentase tertinggi sebesar 26.34\%, disusul secara berurutan oleh indikator argumentation sebesar $26.25 \%$, causal sebesar 25.64\%, dan analogical sebesar $21.77 \%$. Data tersebut menunjukan bahwa sebagian besar siswa sudah mampu mengidentifikasi faktor-faktor dari masalah yang diberikan dan mampu membangun skema konseptual untuk memecahkan masalah. 


\section{Deskripsi Kemampuan Pemecahan Masalah Berdasarkan Sub Materi}

Kemampuan pemecahan masalah siswa pada materi suhu dan kalor mengalami peningkatan dari pretest ke posttest. Hal ini dapat ditunjukan pada Gambar 3 mengenai peningkatan kemampuan pemecahan masalah pada tiap soal yang diberikan.

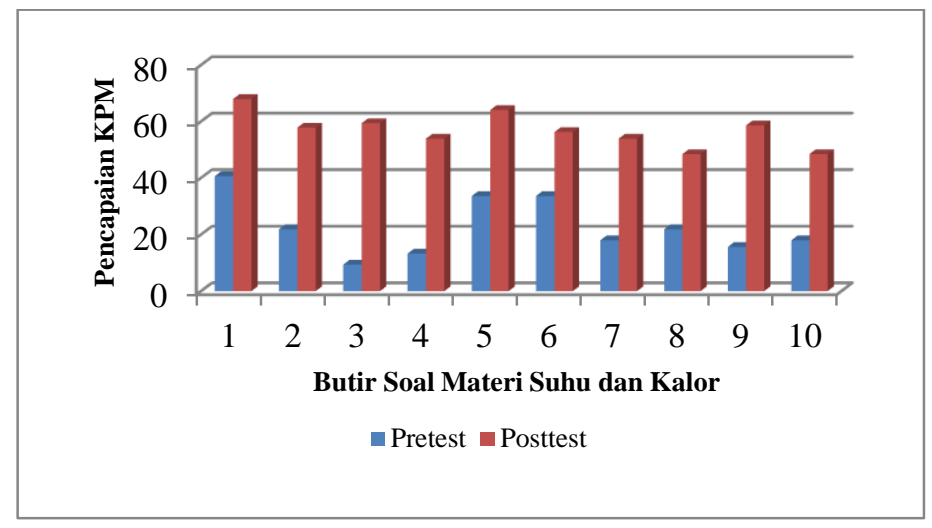

\section{Gambar 3. Kemampuan Pemecahan Masalah Pada materi suhu dan Kalor}

Berdasarkan Gambar 3 terlihat adanya peningkatan kemampuan pemecahan masalah pada tiap butir soal sub materi suhu dan kalor dari pretest ke posttest. Hal tersebut terlihat pada tiap butir soal 1 dan 7 merupakan soal sub materi suhu dan pemuaian, 4, 8, 10 merupakan soal sub bab pengaruh kalor terhadap suhu dan perubahan wujud, 9 merupakan soal sub bab asas black, dan 2,3,5,6 merupakan soal sub bab perpindahan kalor secara konduksi, konveksi, dan radiasi. Berikut contoh perbedaan jawaban siswa pada saat pretest dan protest pada sub bab pemuaian yang ditunjukkan oleh Gambar 4.

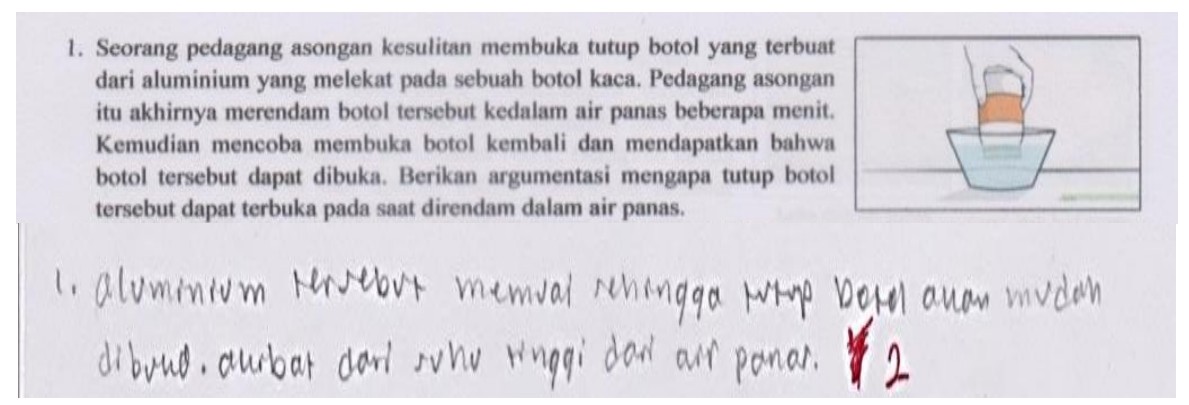

(a)

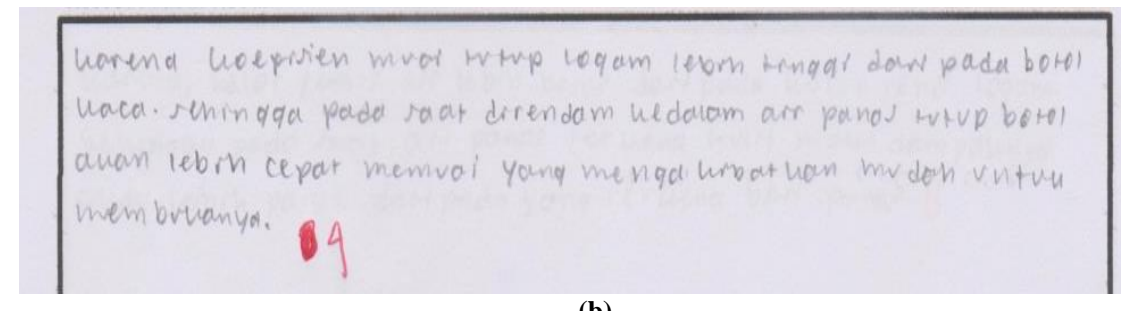

(b)

Gambar 4 (a) Jawaban Pretest, (b) posttest

Gambar 4 menyajikan hasil jawaban pretest dan posttest siswa pada sub bab suhu dan pemuaian. Jawaban siswa pada saat posttest mengalami perubahan setelah diajar menggunakan Experiential learning Berbasis Fenomena. Pada pretest, siswa menjawab secara umum berdasarkan konsep awal yang mereka miliki dan belum menjelaskan secara detail mengapa tutup botol memuai. Pada posttest terlihat bahwa jawaban siswa sudah lebih kompleks dan mengaitkannya dengan konsep pemuaian mengenai adanya perbedaan koefesien muai antara tutup botol dan botol. Siswa sudah menjawab dengan benar yaitu karena koefesien muai tutup botol lebih besar dari pada botol sehingga pada saat direndam kedalam air panas tutup botol akan lebih cepat memuai dan menyebabkan tutup botol dapat terbuka. 


\section{PEMBAHASAN}

Berdasarkan analisis data yang telah dilakukan diperoleh hasil kemampuan pemecahan masalah siswa pada saat posttest lebih tinggi dibandingkan pada saat pretest. Hal ini menunjukkan bahwa kemampuan pemecahan masalah siswa mengalami peningkatan setelah diajar menggunakan Experiential learning berbasis fenomena. Hasil penelitian ini didukung oleh beberapa hasil penelitian sebelumnya yang menunjukkan Experiential learning berbasis fenomena dapat meningkatkan kemampuan pemecahan masalah siswa (Marshall, Carrano, \& Dannels, 2016; Przasnyski \& Elias, 2013). Hal ini desebabkan kerena proses pembelajaran yang menyediakan pengalaman yang beorientasi pada fenomena nyata dapat melatih kemampuan pemecahan masalah bagi siswa (Nurita, Hastuti, \& Sari, 2017). Penelitian yang dilakukan oleh (Moore, 2016) juga menunjukkan bahwa pembelajaran berbasis pengalaman dapat membantu siswa dalam memecahkan masalah yang berkaitan dengan suhu dan kalor melalui fenomena nyata. Experiential learning berbasis fenomena sesuai dengan kebutuhan guru dan siswa di abad 21 yang menghasilkan pembelajaran yang bermakna dengan melibatkan siswa dalam memecahkan masalah yang relevan dengan fenomena nyata (Knobloch, 2003; Kolb \& Kolb, 2008).

Pengalaman yang berorientasi pada fenomena nyata menjadi salah satu tombak kebanyakan siswa yang memengaruhi cara mereka belajar. Hal ini disebabkan karena pengalaman dapat membentuk skema awal siswa tentang suatu konsep dengan cara memadukan pengetahuan baru yang diperoleh dengan skema awal yang tersimpan di long term memory yang diperoleh dari pengalaman masa lalu (Kolb, 2015). Belajar dapat ditempuh melalui pengalaman yang menunjukkan bahwa siswa harus menjalani pengalaman untuk memahami suatu konsep yang dapat dicapai melalui pengamatan fenomena nyata yang ada (Symeonidis \& Schwarz, 2016). Hasil wawancara tidak terstruktur pada beberapa siswa menunjukkan bahwa sebagian besar siswa lebih antusias belajar dengan pembelajaran Experiential learning berbasis fenomena. Hal ini senada dengan penelitian yang dilakukan (Nurita, Hastuti, \& Sari, 2017) yaitu siswa mampu mengembangkan kemampuannya dalam memecahkan masalah pada materi gelombang optik setelah diajar menggunakan Experiential learning. Penelitian yang dilakukan (Kuh, O'Donnell, \& Schneider, 2017) tentang experiential learning berbasis fenomena di bidang pembelajaran memiliki dampak yang signifikan terhadap keberhasilan siswa secara keseluruhan di sekolah. Hal ini terjadi karena, experiential learning berbasis fenomena dapat membantu siswa terutama dalam memamahi konsep melalui penyelidikan yang berasal fenomena yang terjadi dalam kehidupan nyata (Qamariah, Jumadi, Senam, \& Wilujeng, 2017).

Kemampuan pemecahan masalah siswa diukur menggunakan empat indikator, yaitu Argumentation, problem schema, causal, dan analogical. Pada saat posttest keempat indikator dari kemampuan pemecahan masalah mengalami pergeseran kearah yang lebih baik. Indikator problem schema memiliki persentase tertinggi dibandingkan indikator lainya, dan disusul secara berurutan oleh indikator argumentation, causal, dan analogical. Data tersebut menunjukkan bahwa sebagian besar siswa pada saat diberikan suatu masalah, sudah mampu mengidentifikasi faktor-faktor dari masalah yang diberikan dan mampu membangun skema konseptual untuk memecahkan masalah. Selain itu, siswa sudah mampu memberikan argumen yang sesuai dengan masalah yang diberikan, mampu menemukan sebab akibat dari masalah yang diberikan. Hal ini senada dengan penelitian yang dilakukan oleh (Purnamasari, Yuliati, \& Diantoro, 2017) yang menunjukkan bahwa indikator problem schema juga memiliki persentase tertinggi dibandingkan dengan indikator dari pemecahan masalah lainnya. Dengan demikian, proses pembelajaran untuk melatih kemampuan pemecahan masalah siswa harus dirancang untuk membangun problem schema siswa (Vijesh \& Praveen, 2017). Menurut Riley and Greeno (1988) problem schema adalah representasi dari pola informasi yang diwakili dalam masalah. Problem schema diperlukan untuk mengembangkan solusi yang tepat untuk masalah yang diberikan (Vijesh \& Praveen, 2017). Berdasarkan hasil dari wawancara tidak terstruktur beberapa siswa diperoleh bahwa pada saat mengerjakan soal yang berkaitan dengan indikator analogical, siswa merasa kebingungan dalam menemukan dan membandingkan persamaan atau perbedaan dari beberapa masalah yang diberikan. Hal inilah yang menyebabkan indikator analogical memiliki persentase terendah dibandingkan dengan indikator kemampuan pemecahan lainnya.

Kemampuan pemecahan masalah siswa yang digunakan dalam penelitian ini dikelompokkan menjadi empat kategori, yaitu sangat tinggi, tinggi, sedang, dan rendah. Pada saat pretest sebagian besar siswa masih berada dalam kategori rendah. Banyak penelitian yang dilakukan terkait pemecahan masalah yang menunjukkan hasil yang kurang baik. Hasil wawancara tidak terstruktur yang dilakukan kepada beberapa siswa menunjukkan bahwa siswa yang berada dalam kategori rendah memiliki pengetahuan yang terbatas pada definisi dan siswa masih asing terhadap beberapa istilah variabel fisika pada soal. Hal ini senada dengan penelitian yang dilakukan oleh Staggers \& Norcio (1993) yang menunjukkann bahwa tingkat kemampuan pemecahanan masalah yang rendah salah satunya dipengaruhi kemampuan kognitif dan kemampuan representasi penyelesaian masalah yang dilakukan oleh siswa. Selain itu, siswa juga cenderung mamahami masalah berdasarkan besaran yang ada pada soal, kemudian mencocokannya dengan konsep yang memuat besaran tersebut. Setelah Experiential learning berbasis fenomena diterapkan, pada saat posttest terlihat sebagian besar siswa mengalami peningkatan kemampuan pemecahan masalah dari yang rendah dan tidak dapat digolongkan menjadi sedang dan tinggi. Tingginya persentase siswa yang berada dalam kategori "sedang" dan "tinggi" disebabkan karena sebagian besar sudah memiliki pengetahuan yang cukup dan sudah terampil dalam melakukan prosedur dan mentrasfer pengetahuan yang dimiliki dari masalah sebelumnya ke masalah yang baru. Memecahkan permasalah yang baru dapat menjadi lebih mudah ketika siswa dapat membangun pengalaman dengan masalah lain yang telah berhasil dipecahkan (Wareham, Evans, \& Rooij, 2011). 
Berdasarkan hasil wawancara kepada siswa yang memiliki kemampuan pemecahan yang tinggi mengungkapkan strategi yang digunakan saat memecahkan masalah yaitu cenderung memulai dengan mendeskripsikan informasi secara kualitatif terlebih dahulu, dan menggunakan informasi tersebut untuk menentukan strategi yang tepat untuk memecahkan masalah sebelum menuliskan persamaan matematisnya. Siswa juga menggunakan lebih banyak representasi dan menghubungkan konsep-konsep yang berguna dalam memecahkan masalah. Hasil penelitian ini sesuai dengan hasil penelitian sebelumnya yang menunjukkan bahwa siswa hanya menganalisis dan menyelesaikan masalah berdasarkan variabel yang diketahui dalam soal kemudian menerapkannya ke dalam persamaan yang mengandung variabel tersebut tanpa memikirkan kebenaran dari persamaan yang dipilih (Novick \& Sherman, 2008). Hal ini dapat disebabkan karena siswa kurang membangun keterampilan pada saat menerapkan konsep ke dalam proses pemecahan masalah sehingga mengalami kesulitan dalam memecahkan masalah yang lebih kompleks (Walsh, Howard, \& Bowe, 2007). Hal senada ditunjukkan oleh Docktor, Dornfeld, Frodermann, Heller, Hsu, Jackson, \& Yang (2016) yang mengelompokkan kemampuan pemecahan masalah siswa menjadi dua kelompok yaitu expert dan novice. Siswa yang masuk dalam kelompok expert mengartikan suatu masalah dengan teliti dan tepat, sedangkan siswa yang masuk dalam kategori novice mengartikan suatu masalah berdasarkan konteks dan persamaan.

\section{SIMPULAN}

Kemampuan pemecahan masalah siswa mengalami peningkatan setelah diajar menggunakan Experiential learning berbasis fenomena. Hal ini dapat dilihat pada nilai posttest yang lebih tinggi dibandingkan pada nilai pretest. Selain itu, pada saat pretest sebagian besar siswa masih berada dalam kategori rendah, setelah Experiential learning berbasis fenomena diterapkan terlihat sebagian besar siswa mengalami peningkatan kemampuan pemecahan masalah dari yang rendah dan tidak dapat digolongkan menjadi sedang dan tinggi. Tingginya persentase siswa yang berada dalam kategori "sedang" dan "tinggi" disebabkan karena sebagian besar sudah memiliki pengetahuan yang cukup dan sudah terampil dalam melakukan prosedur dan mentrasfer pengetahuan yang dimiliki dari masalah sebelumnya ke masalah yang baru. Kemampuan pemecahan masalah siswa dalam penelitian ini diukur menggunakan empat indikator, yaitu Argumentation, problem schema, causal, dan analogical. Pada saat posttest keempat indikator dari kemampuan pemecahan masalah mengalami pergeseran ke arah yang lebih baik. Indikator problem schema memiliki persentase tertinggi diantara indikator kemampuan pemecahan masalah lainnya, disusul secara berurutan oleh indikator argumentation, causal, dan analogical. Data tersebut menunjukkan bahwa sebagian besar siswa pada saat diberikan suatu masalah, sudah mampu mengidentifikasi faktor-faktor dari masalah yang diberikan dan mampu membangun skema konseptual untuk memecahkan masalah. Selain itu, siswa sudah mampu memberikan argumen yang sesuai dengan masalah yang diberikan dan mampu menemukan sebab akibat dari masalah yang diberikan.

\section{DAFTAR RUJUKAN}

Adams, W. K., \& Wieman, C. E. (2015). Analyzing the Many Skills Involved in Solving Complex Physics Problems. American Journal of Physics, 83(5), 459-467. https://doi.org/10.1119/1.4913923.

Alias, S. N. B., \& Ibrahim, F. B. (2015). Problem Solving Strategy in Balanced Forces. International Journal of Business and Social Science, 6(8), 94-98.

Antwi, V., \& Aryeetey, C. (2015). Students' conception on heat and temperature: A Study on Two Senior High Schools in the Central Region of Ghana. International Journal of Innovative Research and Development, 4(4), 288 - 301.

Argaw, A. S. (2017). The Effect of Problem Based Learning (PBL) Instruction on Students' Motivation and Problem Solving Skills of Physics. EURASIA Journal of Mathematics, Science and Technology Education, 13(3). https://doi.org/10.12973/eurasia.2017.00647a.

Aryani, A. A. S. N., Handayanto, S. K., \& Wisodo, H. (2016). Penguasaan Konsep Siswa SMA pada Materi Suhu dan Kalor. Prosiding Semnas Pendidikan IPA Pascasarjana UM, I.

Celik, H. (2016). An Examination of Cross Sectional Change in Student's Metaphorical Perceptions Towards Heat, Temperature and Energy Concepts. International Journal of Education in Mathematics, Science and Technology, 4(3), 229. https://doi.org/10.18404/ijemst.86044

Docktor, J. L., Dornfeld, J., Frodermann, E., Heller, K., Hsu, L., Jackson, K. A., \& Yang, J. (2016). Assessing student written problem solutions: A problem-solving rubric with application to introductory physics. Physical Review Physics Education Research, 12(1). https://doi.org/10.1103/PhysRevPhysEducRes.12.010130.

Docktor, J. L., Strand, N. E., Mestre, J. P., \& Ross, B. H. (2015). Conceptual problem solving in high school physics. Physical Review Special Topics - Physics Education Research, 11(2). https://doi.org/10.1103/PhysRevSTPER.11.020106

Glaze, A. L. (2018). Teaching and Learning Science in the 21st Century: Challenging Critical Assumptions in Post-Secondary Science. Education Sciences, 8(1), 12. https://doi.org/10.3390/educsci8010012

Gok, T. (2010). The General Assessment of Problem Solving Processes and Metacognition in Physics Education. Eurasian Journal of Physics and Chemistry Education, 2(2), 110-122.

Gonen, S., \& Kocakaya, S. (2009). A Cross-Age Study on the Understanding of Heat and Temperatures. Eurasian Journal of Physics and Chemistry Education, 2(1), 1-15. 
Gorghiu, G., \& Santi, E. A. (2016). Applications of Experiential Learning in Science Education Non-Formal Contexts. The European Proceedings of Social \& Behavioural Science, 320-326. https://doi.org/10.15405/epsbs.2016.11.33.

Jonassen, D. H. (2011). Learning to Solve Problems: A Handbook for Designing Problem-Solving Learning Environments. New York: Routledge.

Kartal, T., Öztürk, N., \& Yalvaç, H. G. (2011). Misconceptions of science teacher candidates about heat and temperature. Procedia - Social and Behavioral Sciences, 15, 2758-2763. https://doi.org/10.1016/j.sbspro.2011.04.184

Kuh, G., O’Donnell, K., \& Schneider, C.G. (2017). HIPs at Ten. Change: The Magazine of Higher Learning, 49(5), 8-16. https://doi.org/10.1080/00091383.2017.1366805

Kolb, A. Y., \& Kolb, D. A. (2008). Experiential Learning Theory: A Dynamic, Holistic Approach to Management Learning, Education and Development. In The SAGE Handbook of Management Learning, Education and Development (pp. 42-68). 1 Oliver's Yard, 55 City Road, London EC1Y 1SP United Kingdom: SAGE Publications Ltd. https://doi.org/10.4135/9780857021038.n3

Kolb, D. A. (2015). Experiential Learning: Experience as the Source of Learning and Development (Second edition). Upper Saddle River, New Jersey: Pearson Education, Inc.

Leura, G. R., Otto, C. A., \& Zitzewitz, P. W. (2011). Misconception Guided Instruction: Conceptual Change in Heat and Temperature. Procedia - Social and Behavioral Sciences, 12, 600-614. DOI: 10.1016/j.sbspro.2011.02.074

Madu, B. C., \& Orji, E. (2015). Effects of Cognitive Conflict Instructional Strategy on Students' Conceptual Change in Temperature and Heat. SAGE Open, 5(3), 1—9. https://doi.org/10.1177/2158244015594662

Mansyur, J. (2015). Teachers' and Students' Preliminary Stages in Physics Problem Solving. International Education Studies, 8(9). https://doi.org/10.5539/ies.v8n9p1

Marshall, M. M., Carrano, A. L., \& Dannels, W. A. (2016). Adapting Experiential Learning to Develop Problem-Solving Skills in Deaf and Hard-of-Hearing Engineering Students. Journal of Deaf Studies and Deaf Education, 21(4), 403-415. https://doi.org/10.1093/deafed/enw050

Mayer, R. E. (2013). Problem Solving - Oxford Handbooks. Problem Solving, 18.

Moore, A. (2016). Experiential Learning in the Thermal Sciences: Introducing and Reinforcing Fundamental Thermodynamics and Heat Transfer Principles to K-12 and Engineering Undergraduate Students, in: 2016 ASEE Annual Conference \& Exposition Proceedings. Presented at the 2016 ASEE Annual Conference \& Exposition, ASEE Conferences, New Orleans, Louisiana. https://doi.org/10.18260/p.26827

Nurita, T., Hastuti, P. W., \& Sari, D. A. P. (2017). Problem-Solving Skill of Science Students in Optical Wave Courses. Jurnal Pendidian IPA Indonesia, 6(2), 341-345. https://doi.org/10.15294/jpii.v6i2.8184

Novick, L. R., \& Sherman, S. J. (2008). The Effects of Superficial and Structural Information on Online Problem Solving for Good versus Poor Anagram Solvers. Q. J. Exp. Psychol. 61, 1098-1120. https://doi.org/10.1080/17470210701449936

OECD. (2016). PISA 2015 Results. In OECD, Excellence and Equity in Education (Vol. 1). OECD Publishing. Retrieved from http://www.oecd-ilibrary.org/education/pisa-2009-technical-report/programme-for-international-studentassessment_9789264167872-2-en

Przasnyski, Z. H., \& Elias, F. G. (2011). An Experiential and Integrative Approach to Problem Solving and Decision Making. Journal of Executive Education, 10(1), 19-42.

Purnamasari, I., Yuliati, L., \& Diantoro, M. (2017). Analisis Kemampuan Pemecahan Masalah Fisika pada Materi Fluida Statis. Seminar Pendidikan IPA Pascasarjarna UM II, 5.

Qamariah., Jumadi., Senam., \& Wilujeng, I. (2017). Validity of "Hi_Science” as Instructional Media Based-Android Refer to Experiential Learning Model. AIP Conference Proceedings 1868, 080007. https://doi.org/10.1063/1.4995191

Sabella, M. S., \& Redish, E. F. (2007). Knowledge Organization and Activation in Physics Problem Solving. American Journal of Physics, 75(11), 1017-1029.

Saavedra, A. R., \& Opfer, V. D. (2012). Teaching and Learning 21st century Skills: Lessons from the Learning Sciences. Apera Conf. Syd. 35

Symeonidis, V., \& Schwarz, J. F. (2016). Phenomenon-Based Teaching and Learning Through the Pedagogical Lenses of Phenomenology: The Recent Curriculum Reform in Finland. Forum Oświatowe, 28(2), 31-47.

Vijesh, K., \& Praveen, M. (2017). A Logical way of Solving Story Problems in Physics. International Journal of Scientific \& Engineering Research, 8(5), 844-849.

Walsh, L. N., Howard, R. G., \& Bowe, B. (2007). Phenomenographic Study of Students' Problem Solving Approaches in Physics. Physical Review Special Topics - Physics Education Research, 3(2), 1-12.

https://doi.org/10.1103/physrevstper.3.020108

Wareham, T., Evans, P., Rooij, I. van. (2011). What Does (and Doesn't) Make Analogical Problem Solving Easy? A Complexity-Theoretic Perspective. The Journal of Problem Solving, 3(2), 30-71. https://doi.org/10.7771/1932-6246.1091. 